\title{
Features of the management activities of A.M. Pozdneev, the founder of oriental studies in the Far East of Russia (late XIX - early XX centuries)
}

\author{
Olga Anatolyevna Trubich $^{1} *$ \\ ${ }^{1}$ Far Eastern Federal University, 8 Sukhanova Str., 690090, Vladivostok, Russia
}

\begin{abstract}
The paper analyzes the management activities of professor-orientalist A.M. Pozdneev, the first director of Oriental Institute in Vladivostok, who also served as the head of the Vladivostok Men's Gymnasium. The study was conducted in the context of the problem of the formation and development of oriental studies in the Russian Far East. It highlights the role of the directorial body in the management of two different educational institutions is particularly important The paper also shows the difficulties of the director's working conditions related to the specifics of the educational process at the university and the gymnasium, the difference in the contingent of students, which required the head to search for various scientific and pedagogical approaches, the ability to work with both the faculty of Oriental Institute and the pedagogical staff of the gymnasium, as well as the territorial remoteness of the Far Eastern outskirts from the center, which significantly complicated the organization and management and administrative activities of the director A.M. Pozdneev. It demonstrates the results of a hard work of Professor A.M. Pozdneev on the implementation of the state policy tasks in the field of development of higher oriental education in the Far East in the conditions of complex international relations with neighboring Asian states.
\end{abstract}

\section{Introduction}

In the context of foreign policy, Russia acts as a Euro-Asian power with its interests in the Asia-Pacific Region (APR), where today the center of world politics is shifted and where multilateral integration processes in the field of economy and trade are actively formed.

In many ways, the position of the Russian Federation depends on the level of development of its Far Eastern region. This special territory with huge natural wealth occupies a strategically important geopolitical position. The Far East of the Russian Federation is the object of close attention of the leading Asia-Pacific countries and is regarded by many of them as the center of economically profitable investment and implementation of various projects.

For the Russian leadership the issues of development of economic cooperation, strategic partnership with neighboring Asia-Pacific countries remain relevant. In strengthening the position of the Russian Federation, regional security and international cooperation acquire importance to counter terrorism and ensure a dialogue between states. The success and completeness of this process is largely due to the presence of highly qualified orientalists, the demand for which increases every year. A modern orientalist is not only a specialist who knows a foreign language, but also an expert in the field of diplomacy, history, culture, economics.

\section{Historiography of the problem and purpose of the study}

The problems of the history of oriental studies in the Russian Far East have always aroused special research interest. Many authors considered the problems of the formation and development of Oriental Institute as the first higher educational institution on the territory of the Far Eastern outskirts engaged in the training of oriental translators (V.M. Serov, 1994; O.P. Elantseva, 2015; O.A. Trubich, 2015, et al.). Some scientific works were devoted to the activities of scientists, professorsorientalists (A.N. Khokhlov, 1994; O.N. Polyanskaya, 2016; A.S. Dybovsky, 2018; O.P. Elantseva, 2019).

Nevertheless, there is no special study in historiography that thoroughly reveals the difficulties and contradictions of the administrative and management activities of Professor A.M. Pozdneev, who at the same time served as a director of Oriental Institute and the Vladivostok Men's Gymnasium.

The subject of the study is the activities of the first director of Oriental Institute A.M. Pozdneev in the context of the geopolitical strategy of the Russian Empire in the second half of the XIX - early XX centuries.

The purpose of the study is to disclose and analyze the features of the administrative and management activities of Professor-orientalist A.M. Pozdneev as a director of Oriental Institute and the Vladivostok Men's Gymnasium.

Research methods are narrative, problem-chronological, comparative.

\footnotetext{
Corresponding author: trubich@mail.ru
} 


\section{Results and discussion}

At the turn of the XIX-XX centuris the political activity of Russia was focused on the Far East. Given the international situation in the Asia-Pacific Region, the authorities of the Russian Empire clearly understood that to a certain extent the successes of military and trade-economic development, as well as the foreign policy are directly dependent on the state and level of development of oriental studies, and the availability of specialists in this area. The socio-political changes carried out by the Russian government on the Far Eastern outskirts during this period required the state to take decisive action in training specialists proficient in Chinese, Korean and Japanese.

Initially, the state used graduates of the Faculty of Oriental Languages of St. Petersburg University to achieve these goals. However, with the increased interest in the Far East it became clear that the deficit in oriental specialists was obvious in central provinces, not to mention sending them to work in the border areas of the empire. If in 1895 three graduates received a diploma of higher oriental education of St. Petersburg University, then in $1898-8$ [RSHA. Vol. 560. Iss. 28. p. 813. L. $142]$.

Another difficulty in Russia was a long time period of almost 10 years, which lasted from the publication of imperial decrees to the creation of higher educational institutions. In particular, the first universities in Siberia appeared in the second half of the $19^{\text {th }}$ century: Tomsk University was founded in 1878, and opened only in 1888. Tomsk Technological Institute, respectively, in 1896 and 1900 (Kinelev V.G., 1995, p. 275). In the Far East this problem was solved dynamically and rapidly. Under the influence of the rapidly changing international foreign policy in Vladivostok, Oriental Institute was created clearly demonstrating the success of the state policy in the field of higher oriental education.

In April 1899, the State Council held a discussion on the need for a regional oriental educational institution. On May 24, 1899 Nicholas II approved the Regulations and faculty of Oriental Institute, imposing a resolution "Be it accordingly" [Bulletin of Oriental Institute, 1900. p. 15]. The educational institution began its work on July 1, and its opening took place on October 21, 1899. Future translators, officials of state administrative bodies and public education, officers, diplomats, entrepreneurs studied at the new university. The Regulation on Oriental Institute determined the term of study - four years.

In various fields of higher, secondary and primary education the Director's Corps played the principal role in the implementation of the state policy. According to item 10 of the Regulation on Oriental Institute, only a graduate of the Imperial St. Petersburg University of the Chinese-Manchu-Mongolian category of the Faculty of Oriental Languages could be appointed the director of the university by the highest decree of the Governing Senate. One of the appointment conditions was the availability of a degree in one of the subjects taught at the university [RSHA. Vol. 560. Iss. 28. 813. L. 28]. The director had to be responsible for the organization of the educational process, the implementation of educational programs, the improvement of the university and many other administrative and economic functions.

In the Far Eastern outskirts the formation and development of higher oriental education is associated with the name of the first director of Oriental Institute - Alexei Matveevich Pozdneev. His candidacy met all the above requirements. He was a graduate of the metropolitan university (1876) in the SinoMongolian-Manchu category. By the time he began his work at Oriental Institute, A.M. Pozdneev was a professor, doctor of Kalmyk and Mongolian literature, and the only specialist in the Manchu language in Russia.
For several years A.M. Pozdneev working at St. Petersburg University acquired organizational and managerial experience by performing the duties of a secretary of the Faculty of Oriental Languages, repeatedly replacing the dean. By the time Oriental Institute was opened, he had the authority and reputation in the Ministry of Education as an orientalist scientist with organizational abilities. The decree on his appointment as the director of Oriental Institute was signed by the Emperor on July 9, 1899 [AOIOM RAS AS. Vol. 44. Iss.1. 51. L. 2].

However, this appointment had a number of important features that formed the specifics of the management activities of the head of the new Far Eastern Institute. The fact is that in order to save money and a small number of students, according to the Regulation on Oriental Institute, the director of a higher educational institution simultaneously managed two educational institutions of different levels - Oriental Institute and the Vladivostok Men's Gymnasium [RSHA FE. Vol. 226. Iss. 1. 73. L. 4-4].

Besides, until 1913 learner officers studied with students. The goals, tasks, content and teaching methods for them differed from students of the gymnasium. This meant that the educational process had to be aligned with the requirements of the higher levels and the service characteristics of the military contingent. Another circumstance complicated the solution of various types of managerial tasks - a huge distance from the capital and the Ministry of Education.

Despite all the difficulties A.M. Pozdneev was able to solve a huge number of issues in the development of oriental studies. So, arriving in Vladivostok he managed to purchase furniture, dishes, linen, order the necessary books, etc. for study rooms and the student dormitory [RSHA. Vol. 733. Iss. 151. 602. L. 6].

In the administrative and management activities of the head a special place was held by the problem of staffing the faculty of the university. In this direction A.M. Pozdneev carried out a lot of work forming a staff corps of teachers of Oriental Institute consisting of 19 people (1 professor, 6 acting professors, 3 teachers, 2 lecturers of European languages, 7 lecturers of oriental languages). The Far Eastern Institute was strengthened by experienced pedagogical personnel. At the same time, an accountant, an economist, an institute doctor were hired, i.e. the director created an economic unit and organized office work at the Institute. As a result, the scientific and pedagogical staff and maintenance personnel provided for by the Regulation on Oriental Institute were staffed [RSHA. Vol. 560. Iss. 8. 29336. L. 62].

Many efforts and funds were applied by Professor A.M. Pozdneev in the creation of an institute library, without which the implementation of new educational programs and scientific plans was not possible. The director established and used two sources of acquisition. First of all, these were metropolitan industrial and trade organizations that supplied the necessary scientific and educational literature to the university. To this end, even before arriving in Vladivostok A.M. Pozdneev addressed the owners of industrial enterprises with a request to help Oriental Institute acquire the necessary literature. Another source for ensuring the high quality of library collections was publications in Chinese, Korean, Japanese, Mongolian languages bought by teachers in eastern countries. So, by the end of the first academic year 1900, the library stock amounted to about 16 thousand units of various publications, in $1902-44$ thousand [RSHA. Vol. 560. Iss. 8. 29336. L. 62].

To improve the quality of training and achieve educational goals, A.M. Pozdneev considered it extremely necessary to create a commercial and industrial museum at the Institute. Due to the attention, concerns and efforts of the director in 1902, the collection of the Institute Museum contained 3329 diverse exhibits, as well as 11065 individual objects, which significantly expanded the possibilities of the educational process and the 
scientific and cognitive outlook of students [RSHA FE. Vol. 226. Iss. 1. 58. L. 22].

A.M. Pozdneev introduced a new teaching method, which included the development of modern textbooks by teachers, separate training in foreign languages: with professors for theoretical classes and with a native speaker (Chinese, Japanese, Korean) for practical classes. A system of summer trips of students and officers to the country of the studied language was also practiced. In teaching oriental languages, A.M. Pozdneev introduced spoken and bookish way of speaking. The latter varied in styles - newspaper, official, commercial, diplomatic. This indicated the intention to teach students practical foreign language skills.

The educational program of Oriental Institute faced a number of difficulties due to household problems. In this direction A.M. Pozdneev also made a lot of efforts. In particular, it took almost a year to complete the institute building and gymnasium facilities. In the new building, classes began on September 1, 1900. The institute was located on the first floor and included a recreational hall for students, 5 classrooms for 40 people, a teaching room [RSHA FE. Vol. 702. Iss. 3. 328. L. 1] The number of students increased every year, which required the opening of additional study rooms. The director reviewed the redevelopment projects and implemented them as far as possible. So, due to the reconstruction in 1901, 3 more rooms were added [Bulletin of the Eastern Institute, 1901. p. 87]. However, the problem of the shortage of classrooms did not disappear. The university management was forced to take the museum premises for classes, and museum exhibits were placed in classrooms, corridors and even under stairs.

The problems of the technical maintenance of the university building, the internal and external improvement of the educational building also needed the special attention of the director. These goals were partially implemented in 1901-1902. In particular, the roof, courtyard, sidewalks were repaired. Internal repairs were carried out in rooms, floors were painted, parquet was laid in the assembly hall, etc. All this required money, the sourcing for which was also carried out by the director of the university [Bulletin of the Eastern Institute, 1903. p. XXXIII].

The successful work of the director was ensured by an established relationship with central and local authorities. In solving many issues A.M. Pozdneev relied on professional contacts that he established during his work at St. Petersburg University. Visiting the capital to meet with the representatives of the Ministry of Education, the director focused on the needs of Oriental Institute. For example, in 1901, after discussing a number of issues with Minister P.S. Vannovsky, the total amount of funds allocated by the Ministry of Education for the repair of a student boarding school was 3.5 thousand rubles [RSHA FE. Vol. 702. Iss. 3. 328. L. 2]. Nevertheless, during 1902-1903 in business correspondence, reporting documents and accompanying notes, at receptions of the Minister of Education, the director of the university repeatedly pointed to an extremely small area of the student boarding school, but this problem was solved only a few years later [RSHA FE. Vol. 702. Iss. 3. 328. L. 3].

A.M. Pozdneev was the head of Oriental Institute from 1899 to 1903 . He stood at the origins of the higher oriental education. All his merits were noted by the Decree of Emperor Nicholas II of November 12, 1902. The Director of Oriental Institute A.M. Pozdneev was increased his salary in the amount of 2 thousand rubles per year for his participation in the planning of Oriental Institute, organizing the university publication Bulletin of Oriental Institute [RSHA. Vol. 744. Iss. 1. 194. L. 44].

The object of the scientific journal was social aspects, features of life, culture, religion, trade, transport, and the state structure of neighboring eastern countries. Over time, the journal gained popularity and was distributed throughout Russia.
Higher educational institutions and interested government structures (ministries, Russian embassies abroad and foreign embassies in Russia, state institutions of the Amur Territory and even Emperor Nicholas II) received it free of charge. The Institute journal attracted the attention of foreign orientalists. The Otto Garrosowitz book company became a special comissioner for Western Europe. Amur Governor-General N.P. Linevich noted that the university developed due to the efficiency, commitment and proactivity of A.M. Pozdneev [History of the Far Eastern State University in documents and materials. 1899-1939, 2004. p. 73].

In the three years since the opening of the institute, the administration and faculty under the leadership of A.M. Pozdneev put in a lot of effort to create optimal conditions for the success of the educational process in the Far Eastern university. Clearly realizing the main educational task aimed at ensuring the qualitative development of the potential of future oriental linguists the first director of Oriental Institute sought to focus graduates on professional activities in state institutions, the banking system, the field of education, etc.

In the future, the set objectives, on the one hand, contributed to the development of higher linguistic studies in the Far Eastern outskirts. On the other hand, the established system of higher education and the level of training allowed future young orientalists applying their knowledge not only within the region, but also in the ministries and departments of the central part of the Russian Empire [Table 1].

Table 1. Employment indicators for graduates of Oriental Institute (1904-1920) (SAPK. Vol. 115. Iss. 2. 5. L. 2-3, 9-9, 3985; 8. L. 4-127; 10. L. 31-94; 13. L. 96-134).

\begin{tabular}{|c|c|}
\hline $\begin{array}{c}\text { State ministries and departments of the } \\
\text { Russian Empire }\end{array}$ & $\begin{array}{c}\text { Number of } \\
\text { graduates of } \\
\text { the Eastern } \\
\text { Institute }\end{array}$ \\
\hline Ministry of Internal Affairs & $12 \%$ \\
\hline Ministry of Finance & $11 \%$ \\
\hline Ministry of Foreign Affairs & $9 \%$ \\
\hline Ministry of Education & $7 \%$ \\
\hline China Eastern Railway & $7 \%$ \\
\hline $\begin{array}{c}\text { General Directorate of Agriculture and } \\
\text { Land Management }\end{array}$ & $5 \%$ \\
\hline Ministry of Trade and Industry & $2 \%$ \\
\hline Ministry of Justice & $2 \%$ \\
\hline Department of Religious Affairs & $2 \%$ \\
\hline
\end{tabular}

One of the important indicators of the success of Oriental Institute was the personnel indicator. Young specialists of the Far Eastern Institute were in demand not only in the territory of the Russian Empire, as noted above, but also in foreign countries [Table 2].

The data presented above indicate that graduates applied their linguistic and other humanitarian knowledge obtained at the Far Eastern Institute in various fields. The obtained wealth of knowledge, versatile intellectual potential gave them a wide opportunity for the practical application of their linguistic skills and abilities. Young specialists easily found work at Russian and Chinese customs, worked as translators in civilian and military structures. Dragomen were in demand in eastern countries, some twisted their fortune with China, Japan as correspondents and newspaper editors.

Another important component of the pedagogical and administrative-economic activities of A.M. Pozdneev was the obligation to manage the Vladivostok Men's Gymnasium providing training to 59 people students. The peculiarity of this type of educational institution was the implementation of the 
secondary general education program. The structure of the gymnasium included a director, teachers, class mentors, a clergyman, a gymnasium doctor, and students. According to the Charter, there were such collegiate governing bodies in the gymnasium as pedagogical, parental and guardianship councils. Their duties included organizing the meals of students, purchasing textbooks, helping poor students, etc.

Table 2. Held positions of graduates of Oriental Institute in the Russian Empire and abroad (SAPK. Vol. 115. Op. 2. 5. L. 23, 9-9, 39-85; 8. L. 4-127; 10. L. 31-94; 13. L. 96-134).

\begin{tabular}{|c|c|c|}
\hline $\begin{array}{c}\text { Administrative-territorial } \\
\text { unit in Russia/foreign } \\
\text { states }\end{array}$ & $\begin{array}{c}\text { Positions held by } \\
\text { the graduates of the } \\
\text { Eastern Institute }\end{array}$ & $\begin{array}{c}\text { Quantita } \\
\text { tive } \\
\text { index }\end{array}$ \\
\hline $\begin{array}{c}\text { Vladivostok, Nikolsk- } \\
\text { Ussuriysk, Trans-Baikal } \\
\text { Region (Russia)/Beijing, } \\
\text { Harbin, Hankou (China) }\end{array}$ & Teachers & $31 \%$ \\
\hline $\begin{array}{c}\text { St. Petersburg, } \\
\text { Vladivostok } \\
\text { (Russia)/Harbin, Beijing, } \\
\text { Shanghai (China) }\end{array}$ & Bank employees & $18 \%$ \\
\hline $\begin{array}{c}\text { Vladivostok, } \\
\text { Pogranichnoe, St. } \\
\text { Petersburg } \\
\text { (Russia)/Shanghai, Harbin } \\
\text { (China) }\end{array}$ & Customs officers & $10 \%$ \\
\hline $\begin{array}{c}\text { Hankou, Kuang-cheng- } \\
\text { tzu, Chuguchak }\end{array}$ & Secretaries & $9 \%$ \\
\hline $\begin{array}{c}\text { Harbin (China), Tokyo } \\
\text { (Japan) }\end{array}$ & Newspaper editors, \\
\hline $\begin{array}{c}\text { Tokyo (Japan), Seoul } \\
\text { (Korea), Mukden, } \\
\text { Kulzhda (China) }\end{array}$ & Dragomen & $7 \%$ \\
\hline $\begin{array}{c}\text { General Directorate of the } \\
\text { General Staff, Amur } \\
\text { Military District (Russia) }\end{array}$ & Translators & $7 \%$ \\
\hline $\begin{array}{c}\text { Urga, Bodong, Girin } \\
\text { (China) }\end{array}$ & Commercial agents \\
\hline $\begin{array}{c}\text { Primorsky, Amur, Irkutsk } \\
\text { regions (Russia) }\end{array}$ & Peasant chiefs & $6 \%$ \\
\hline
\end{tabular}

The highest governing body of the gymnasium was the Pedagogical Council, which performed educational functions. The main tasks of the Pedagogical Council were the implementation of the state policy on secondary education, the introduction of advanced pedagogical experience into practice, the solution of issues of admission, transfer, graduation, etc., and it also made decisions on encouraging or punishing students. Each individual case was considered in detail with clarification of the reasons for students' behavior. The student's disciplinary misconduct was considered a violation of the Charter of the gymnasium and the rules of internal procedure. Smoking, street hooliganism, skipping lessons, and many others were considered the reasons for disciplinary infraction [RSHA FE. Vol. 138. Iss. 1. 15. L. 4, 6, 8].

The results of student performance became the subject of discussion at the meetings of the Pedagogical Council. The analysis of the minutes of the meetings shows that the issues related to the material support of the gymnasium (furniture, stationery, wood for heating the room, etc.) were also put on the agenda [RSHA FE. Vol. 138. Iss. 1. 6. L. 60].

The leading role in the activities of the Men's Gymnasium was assigned to the director, who resolved administrative, personnel, economic and financial issues. At the same time, dozens of different events required the direct presence of the head. A.M. Pozdneev chaired the Pedagogical Council. Joint decisions with colleagues were the result of a competent and effectively organized educational process. Various issues deserved separate attention and effort throughout the academic year. For example, due to the change in curricula, it was necessary to quickly adjust the curricula, forms and methods of organizing the educational process.

Education in the gymnasium was fee-based, but many families experienced certain financial difficulties. In this regard, parents wrote appeals for installments or cancellation of payments detailing the reasons to the director. After a personal and thorough consideration of the petitions, these requests were submitted by A.M. Pozdneev for discussion to the Pedagogical Council for a collegial decision on the matter.

Administrative documents were of great importance for the public education system of the Russian Empire, for example, circulars of the Ministry of Education, which served as a legal act. They reflected specific legal authority to carry out managerial tasks. Receiving such documents, A.M. Pozdneev discussed their content with the pedagogical staff of the gymnasium. As noted in the minutes of the meetings of the Pedagogical Council, each teacher had the opportunity to participate in the discussion on the general decision. In particular, in April 1900 A.M. Pozdneev presented a resolution of the Ministry of Education on the abolition of translation exams for successful students to the teachers of the gymnasium. The teachers supported the director in the possibility of implementing the transfer of a student from class to class based on the results of annual assessments [RSHA FE. Vol. 138. Op. 1. 6. L. 39. Id. Vol. 226. Iss. 1. 73. L. 44].

In March 1901 the gymnasium received the next ministerial circular "On vacation student excursions", according to which it was to become the organizer of summer events for students. The Pedagogical Council, together with the director, developed an excursion plan. Younger schoolchildren were introduced to the history and structure of Vladivostok, the features of local flora and fauna. For mid-level students, excursions were organized to factories, they were introduced to the peculiarities of classes of Russian, Chinese, Korean peasants, linguistic aspects. High school students traveled to the village of Shkotovo and the monastery near the village of Shmakovka [RSHA FE. Vol. 138. Iss. 1. 6. L. 39. Id. Iss. 2. 29. L. 7-8].

The administrative activity of A.M. Pozdneev conditioned the adoption of not always simple managerial decisions. The director had to delve into and deal with conflict situations with personal or educational implication. Thus, in December 1902 students of the $7^{\text {th }}$ grade refused to perform an exercise on translating the text from Latin into Russian and did not appear in class. The students explained their behavior by the fact that the teacher applied higher criteria to translations than to oral speech, so they received lower marks. The teacher believed that the exercise was not difficult, the students simply did not try to understand the task, and the use of different forms and methods provided a comprehensive assessment of the results. A.M. Pozdneev personally considered this case making a constructive decision: the disrupted class was postponed to Sunday, and the students had to fulfill the necessary task [RSHA FE. Vol. 138. Iss. 1. 6. L.15-16].

In general, the management activities of A.M. Pozdneev, the director of two different educational institutions, can be considered as a multifactorial process in which an orientalist professor proved himself as an administrator and organizer, as well as a scientist. Dealing simultaneously with the issues of the higher educational Oriental Institute and the Vladivostok Men's Gymnasium, the director spent a significant amount of time on official correspondence with heads of various levels (Amur Governor-General, school inspectors of the Amur Territory, etc.). In numerous reports and petitions he thoroughly and in detail disclosed the content of each case, the essence of each 
request, substantiated his position in detail, and made rational proposals.

For example, at the beginning of the 1900 academic year, by the order of the district inspector on the maximum number per class, A.M. Pozdneev came to the conclusion that the first and preparatory classes were overcrowded. In his opinion, the current situation caused the need to create parallel classes, which entailed an increase in the staff of gymnasium teachers and, accordingly, an increase in centralized funding. In correspondence with the district school inspector of the Amur Region and the Amur Governor-General he gave calculations for paying salaries to teachers mentioning that the parallel classes should not become a burden for the Treasury. The problem could be solved by the educational institution itself, i.e. to increase the tuition fee to 40 rubles annually and hire teachers of Russian and ancient languages [RSHA FE. Vol. 138. Iss. 1. 6. L. 103 - 104]. As a result, the local authorities supported this proposal by A.M. Pozdneev at all levels, and the issue was resolved in favor of the Men's Gymnasium.

Leading two educational institutions with different levels of training at the same time, A.M. Pozdneev was a kind of link between the higher authorities, the faculty of the higher educational institution and the pedagogical staff of the gymnasium. For the development of both the university and the gymnasium, he had to solve a huge number of diverse tasks ranging from organizing the educational process, preparing textbooks, ending with the staffing issues, etc.

\section{Conclusion}

The higher oriental education in the Far East of the Russian Empire in the late XIX - early XX centuries was formed and developed in the national context being an important component of the national strategy.

A retrospective analysis of the features of the management activities of A.M. Pozdneev, the director of the university and the gymnasium, during the chronological period showed that his work was largely dependent on the capital and local authorities, in the ability to make the right decisions that minimized possible negative consequences, ability to prioritize and take into account the interests of the parties, scientifically and rationally ensure the success of the educational process. At the same time, he always remained an oriental scientist who was deeply aware of his personal state strategic tasks.

Definitely, the leadership of the gymnasium took a great deal of time and effort, but this activity opened the prospect for the formation of a future contingent of students of the Eastern Institute.

The difficulties of teaching students to a certain extent were to be compensated by decent living conditions at the new university, which was the subject of concern and care of A.M. Pozdneev. Laying the groundwork for material resources and research funds (library, museum), the proficient organization of the educational process and staffing in many ways contributed to the implementation of the tasks of the Eastern Institute.

For three years of work at the Eastern Institute A.M. Pozdneev created a special university infrastructure without which the functioning of the first higher educational institution in the Far East was not possible. The initiated mechanism first of all contributed to the development of oriental studies. A.M. Pozdneev also laid the foundation for publishing activity. The Bulletin of the Eastern Institute he created later was of paramount importance for orientalists and specialists working with the representatives of Asian business circles.

A new breakthrough was first made in teaching oriental languages at the initiative of A.M. Pozdneev, which further raised the educational level of future oriental linguists who had to work in the system of international relations. It was A.M.
Pozdneev who determined the initial focus on practical training, which paved the way for modern Russian oriental studies and the transition from traditional oriental studies, which developed under the influence of classical historical and literary views. This trend continued throughout the existence of Oriental Institute and was taken as the basis for other linguistic educational institutions.

The most important result of the activities of A.M. Pozdneev both as a director and as a teacher-professor in the formation and development of Russian oriental studies in the Far East is the quantitative indicators of graduates of the Eastern Institute. It was due to the efforts of the first director that in 1903 the first graduation of orientalists (10 people) strongly needed for the Far Eastern outskirts actually happened. By the beginning of the $20^{\text {th }}$ century, 400 oriental specialists from among student officers and university students were already working in diplomatic, financial, commercial, military and other institutions of Russia and abroad. Of these, the majority (73\%) worked in the Russian Empire, the remaining 27\% - in China, Korea, Japan and other countries of the East.

\section{References}

1. Archive of orientalists of the Institute of Oriental Manuscripts of the Russian Academy of Sciences (AOIOM RAS).

2. State Archive of Primorsky Krai (SAPK).

3. A.S. Dybovsky, Historical and socio-educational thought, 10(4/2), 83-105 (2018).

4. O.P. Elantseva, O.A. Trubich, Social Studies and Humanities in the Far East, 2, 26-32 (2015).

5. O.P. Elantseva, Bulletin of Oriental Institute, 3 (43), 123132 (2019).

6. History of the Far Eastern State University in documents and materials. 1899-1939 (Vladivostok: Dalnauka, 2004).

7. Bulletin of Oriental Institute. I(1) (Vladivostok, 1900).

8. Bulletin of Oriental Institute. II(2) (Vladivostok, 1901).

9. Bulletin of Oriental Institute. V (Vladivostok, 1903).

10. V.G. Kinelev, Higher education in Russia: Essay on history until 1917 (Moscow: NII VO, 1995).

11. O.N. Polyanskaya, Scientific notes of Transbaikal State University. Ser.: Professional education, theory and teaching methodology, 11(6), 143-148 (2016).

12. Russian State Historical Archive (RSHA).

13. Russian State Historical Archive of the Far East (RSHA FE).

14. V.M. Serov, Bulletin of Oriental Institute of the Far Eastern State University, 1, 14-36 (1994).

15. A.N. Khokhlov, Bulletin of Oriental Institute, 1, 37-47 (1994). 